\title{
KEWENANGAN BADAN PENGAWAS OBAT DAN MAKANAN TERHADAP PERDA PROVINSI BALI NO 5 TAHUN 2012 TENTANG PENGENDALIAN PEREDARAN MINUMAN BERALKOHOL
}

Oleh :

I PUTU MAHENTORO

(Mahasiswa Magister Hukum Konsentrasi Hukum Pemerintahan)

\begin{abstract}
The research was conducted based on the same authority which is owned by the two institutions, namely Food and Drug Administration of the Republic of Indonesia and Bali Provicial Government in monitoring and controlling of alcoholic beverages in Bali.

The results of this study demonstrate the Food and Drug Administration and the Provincial Government of Bali have the same authority to supervise and control alcoholic beverages in Bali. Bali Local Government Regulation Number 5 of 2012 on the Circulation of Alcoholic Beverage Control only requires each has a label on alcoholic beverages issued by the Government of Bali has to be distributed to the public, while the authority of the Food and Drug Administration is regulated in the Regulation of Minister of Health of the Republic of Indonesia Number 382/MENKES/PER/VI/1989 on Registration of Food that requires all food produced both by local producers and imported foods are required to be registered to the Ministry of Health through the Food and Drug Administration.

In the Regulation Number 5 Year 2012 did not include the authority of the Food and Drug Administration (the Empty Norms) so that the Food and Drug Administration can not perform optimally the law enforcement against manufacturers, distributors and sellers of alcoholic beverages in violation. To cope with the condition it should be a amendment in the Bali Provincial Regulation Number 5 of 2012 by stating firmly and clearly the authority of the Food and Drug Administration related to the registration of food, which requires that for all foods and beverages that will be distributed to the public must be registered to the Ministry of Health through the Food and Drug Administration.
\end{abstract}

Keywords : Authority, Legal certainty, Alcoholic Beverages 


\section{I . PENDAHULUAN}

\section{Latar Belakang Masalah}

Bagi manusia makanan atau pangan berguna untuk menghasilkan tenaga sehingga bisa beraktivitas dan melakukan kegiatan. Mengingat manfaat pangan yang demikian penting, maka dapat dikatakan pangan merupakan kebutuhan manusia yang sangat mendasar. Tersedianya pangan yang cukup, aman, bermutu dan bergizi merupakan kewajiban Negara ( state obligation) dalam melakukan pemenuhan hak asasi manusia warganya khususnya dalam pemenuhan Hak -hak ekonomi, sosial dan budaya khususnya hak atas pangan . kondisi pangan yang baik juga menjadi prasyarat utama dalam kehidup yang harus dipenuhi suatu Negara dalam upaya mewujudkan insan yang berharkat dan bermartabat. ${ }^{1}$.

${ }^{1}$ Suryana, Achmad., 2003, Kapita Selekta Pemikiran Kebijakan Ketahanan Pangan, Cet Pertama, BPFE-yogyakarta, Yogyakarta, hal 95.
Pemerintah Indonesia telah menetapkan Undang-Undang Republik Indonesia tentang Pangan Nomor 7 Tahun 1996. Dalam undang-undang tersebut diuraikan pangan merupakan segala sesuatu yang berasal dari sumber hayati dan air, baik yang diolah maupun tidak diolah, yang diperuntukkan sebagai makanan atau minuman, bahan tambahan pangan, bahan baku pangan dan bahan lain yang digunakan dalam proses pembuatan makanan atau minuman juga golongkan kedalam pangan. Dari uraian tersebut maka jelaslah bahwa pangan merupakan sesuatu yang dapat dikonsumsi bagi manusia baik itu berupa makanan maupun minuman yang bersumber dari sumber daya hayati maupun air.

Untuk melakukan pengawasan terhadap makanan agar aman dikonsumsi oleh masyarakat maka Presiden telah membentuk sebuah badan yang diberikan tugas tertentu dalam hal pengawasan terhadap obat dan makanan yang disebut 
dengan Badan Pengawas Obat dan Makanan yang disingkat dengan Badan POM. Badan inilah dengan dikordinasikan oleh Menteri Kesehatan dan Menteri Kesejahteraan Sosial yang diserahkan tugas pengawasan peredaran obat dan makanan di Indonesia, yang dibentuk di masing-masing provinsi di seluruh Indonesia

Dalam melakukan pengawasan obat dan makanan Menteri kesahatan telah mengeluarkan Peraturan Menteri Kesehatan Republik Indonesia Nomor tentang Pendaftaran Makanan dan minuman yang mewajibkan semua bahan makanan baik yang diproduksi produsen maupun yang di impor diwajibkan untuk mendaftarkan makananya ke menteri kesehatan. sebagaimana ketentuan Pasal 4 ayat 1 Permenkes 382/MENKES/PER/VI/1989. dan bagi para pihak yang telah mendaftarkan makanannya berdasarkan Peraturan Pemerintah No. 69 tahun 1999 tentang Label dan Iklan Pangan, dalam Pasal 30 diwajibkan mencantumkan nomor pendaftaran pangan pada label pangan olehannya.

Berkaitan dengan tugas pengawasan pangan dalam bentuk minuman Badan Pengawas Obat dan Makanan juga memiliki tugas untuk melakukan pengawasan dan pengendalian terhadap produksi, pengedaran, penjualan dan penyajian minuman beralkohol. Minuman beralkohol ini merupakan minuman yang mengandung ethanol yang diproses dari bahan pertanian yang mengandung karbohidrat dengan cara permentasi dan destilisasi. Minuman beralkohol dapat juga diproses dengan cara fermentasi tanpa dilakukan destilisasi, baik dengan cara memberikan perlakuan terlebih dahulu atau tidak dan menambahkan bahan lain atau tidak, selain itu minuman beralkohol juga termasuk minuman yang diproses dengan cara mencampur konsentrat dengan ethanol atau dengan cara pengenceran minuman mengandung alkohol. 
Pengawasan minuman beralkohol

ini menjadi penting mengingat

mengkonsumsi minuman beralkohol secara berlebihan dapat mengganggu kesehatan dan ketentraman dan ketertiban masyarakat. Secara umum dampak yang dapat ditumbulkan karena minuman yang mengandung alkohol adalah gangguan kesehatan baik Fisik, Gangguan Jiwa dan Gangguan kamtibmas ${ }^{2}$. Gangguan fisik berupa menyebabkan kerusakan hati,ginjal jantung,dan peradangan lambung, mengganggu metabolisme tubuh, impotensi bagi perempuan menyebabkan kemadulan serta gangguan seks lainnya, Mengkonsumsi minuman Minuman beralkohol secara terus menerus juga dapat menyebabkan gangguan jiwa karena minuman beralkohol merusak secara jaringan otak sehingga menimbulkan gangguan daya ingatan menurun, kemampuan penilaian, dan gangguan jiwa tertentu. Dan yang tidak kalah

2 Ithalabo, blog,DampakMminuman Keras, senin 8 juni 2012 menganggunya bahwa minuman beralkohol dapat membawa dampak pada keamanan dan ketertiban masyarakat (Kamtibmas), orang yang mengkonsumsi minuman beralkohol dapat menyebabkan mabuk, dan orang mabuk biasanya kehilangan pengendalian diri sehingga yang bersangkutan menjadi mudah tersinggung, berani dan agresif. Bagi mereka yang kecanduan alkohol bahkan dapat menimbulkan prilaku tindak pidana atau kriminal guna memperoleh uang untuk memberli minuman dengan cara yang cepat.

Selain berdampak negative, ternyata disisi lain minuman beralkohol dapat memberikan nilai ekonomis yang tinggi dengan pengenaan pajak dan cukai yaitu Pajak Pertambahan Nilai Barang Mewah (PPNBM). Menurut Juru Bicara Gabungan Industri Minuman Malt Indonesia (GIMMI) Ipung Nimpuno Industri bir nasional pun menjadi pembayar pajak terbesar, dengan menghasilkan sekitar $\mathrm{Rp} 1,5$ triliun dari 
PPNBM dan cukai untuk pemerintah per Januari 2012 belum lagi Industri ini mempekerjakan tak kurang dari 10 ribu tenaga kerja baik langsung maupun tidak langsung, dan jutaan lainnya yang mendapat manfaat dari sektor pariwisata. ${ }^{3}$

Bali dikenal sebagai Pulau Dewata (island God) menjadi tempat wisata terbaik di Indonesia bahkan dunia. Sebagai pulau tujuan pariwisata dunia, Bali harus menyediakan minuman berakohol karena sebagaian besar orang asing yang berkunjung ke Bali mengonsumsi minuman berakohol sehingga mendatangkan pemasukan bagi daerah yang sangat besar. Pemasukan dari minuman keras di Bali diperoleh dari biaya cetak Label Edar, Pendapatan dari biaya cetak label minuman beralkohol (mikol) tersebut rata-rata per

\footnotetext{
${ }^{3}$ Miras Bukan Lagi Barang Mewah: Harus Dikendalikan dengan UU, by Neo KPPP ASI (Komunitas Pengamat Pengkaji Pengamal Aqidah Syariat Islam) on Sunday, January 15, 2012 at 6:21pm.
}

bulannya mencapai Rp. 2000.000.000. ( dua milyar Rrpiah). Pengganti biaya cetak label masing-masing golongan mikol tersebut berbeda-beda, sesuai dengan golongan kadar alkohol, yaitu jenis golongan A atau kadar alkohol 0 sampai 5 persen sebesar Rp500 (lima ratus rupiah), golongan B beralkohol 5 sampai 20 persen sebesar Rp1.000 (seribu rupiah) dan golongan $\mathrm{C}$ beralkohol diatas 20 persen sampai 55 persen sebesar Rp1.500 (seribu limaratus rupiah) ${ }^{4}$.

Kewajiban para distributor minuman beralkohol untuk menggunakan label adalah mengacu pada Peraturan Daerah Provinsi Bali Nomor 9 Tahun 2002 tentang Pengawasan dan Pengendalian Peredaran Minuman Beralkohol yang selanjutnya sejak tanggal 14 Juni 2012 telah dirubah dengan Peraturan nomor 5 tahun 2012 Daerah Provinsi Bali tentang Pengendalian Peredaran Minuman Beralkohol. Pengaturan

$\begin{array}{ccc}4 & \text { http:// } & \text { balinews.blog.com }\end{array}$


minuman beralkohol di Bali dimungkinkan diatur melalui Perda di dasarkan pada Peraturan Pemerintah tentang Pembagian Urusan Pemerintah antara Pemerintahan Daerah Provinsi dan Pemerintahan Daerah Kabupaten Kota Nomor 38 Tahun 2007 yang mengamanatkan perdagangan minuman beralkohol merupakan urusan pemerintahan daerah.

Dalam pasal 10 Perda Bali No 5 tahun 2012 tentang Pengendalian peredaran minuman berakohol telah diatur beberapa hal yang wajib dilakukan oleh pengusaha, distributor atau pengedar minuman beralkohol antara lain : pertama, Minuman Beralkohol produksi luar negeri (impor) dan produksi dalam negeri yang diedarkan di masyarakat wajib dikemas, menggunakan pita cukai dan label edar. Kedua, Minuman beralkohol yang di produksi tradisional untuk konsumsi yang di edarkan oleh kelompok usaha atau koperasi wajib dikemas dengan menggunakan label edar, dan ketiga untuk minuman beralkohol produksi secara tradisional yang tidak untuk dikonsumsi dan diedarkan oleh kelompok usaha atau koperasi peredarannya dengan menggunakan label untuk upacara (tetabuhan) dan lebel edar

Dengan ketentuan tersebut maka dapat di telusuri bahwa tidak ada satupun klausule dalam Perda Bali No 5 tahun 2012 tentang Pengendalian peredaran minuman berakohol yang mewajibkan kepada pihak pengimpor, pemproduksi, pengedar dan pengecer untuk melengkapi minumannya dengan mencantumkan nomor pendaftaran pangan pada label pangan olahannya.

Sebuah minuman berakohol import dan produksi dalam negeri sudah dapat di edarkan di masyarakat apabila tememiliki kemasan, pita cukai dan label edar . Bagi minuman beralkohol yang diproduksi secara tradisonal cukup hanya mencantumkan label edar maka sudah dapat di edarkan di Bali tanpa perlu 
mencantumkan nomor pendaftaran pangan pada label pangan olahannya .

Kondisi inilah yang kemudian menimbulkan persoalan didalam pelaksanaan pengendalian dan pengawasan minuman beralkohol di Bali, terdapat dua lembaga yang memiliki kewenangan untuk melakukan pengawasan dan pengendalian minuman beralkohol yang pertama Badan POM dan yang kedua Pemerintah Daerah provinsi Bali demikian pula dari segi aturan terdapat peraturan yang berbeda bagi kedua lembaga tersebut yaitu Perda Bali No 5 tahun 2012 tentang Pengendalian peredaran minuman berakohol dan Peraturan Menteri Kesehatan Republik Indonesia No 382/MENKES/PER/VI/1989 tentang Pendaftaran Makanan. Dampaknya adalah Badan POM tidak dapat dilaksanakan dengan teges tugas penegakan hukum "law enforcement" terhadap produsen, distributor, penjual dan pengecer minuman beralkohol yang melanggar.

\section{Rumusan Masalah}

Dari uraian latar belakang masalah tersebut maka dapat ditarik rumusan masalah yang akan dikaji adalah Kewenangan Badan Pengawas Obat dan Makanan dalam melakukan pengawasan dan pengendalian minuman beralkohol dikaitkan dengan Perda Bali No 5 tahun 2012 tentang Pengendalian peredaran minuman berakohol di Bali

\section{Tujuan Penulisan}

Mengetahui secara lebih mendalam kewenanganya BPOM dalam melakukan pengawasan, pengendalaian dan peredaran minuman beralkohol di Provinsi Bali, mengingat BPOM dan pemerintahan daerah Bali memiliki kewenangan dalam hal pengendalian dan pengawasan terhadap minuman beralkohol 


\section{METODE PENELITIAN}

Penelitian yang dilakukan dengan menggunakan menggunakan metode penelitian hukum normatifyang bersifat deskriftif analitis. Dalam pembahasan penelitian ini menggunakan pendekatan undang-undang yang bersumber bahan hukumnya diperoleh dari hasil penelitian kepustakaan terhadap bahan-bahan hukum yang bersumber pada peraturan perundangundangan yang mengatur tentang pengawasan minuman beralkohol dan literature-literatyur yang berkaitan dengan keweangan pengawasan dan pengendalian minuman beralkohol

\section{HASIL DAN PEMBAHASAN}

wewenang itu menjadi dasar hukum untuk bertindak dan mengambil keputusan tertentu, dan kerenanya kewenangan harus diatur dalam peraturan perundang-undangan sehingga menjadi dasar legitimasi bahwa sebuah lembaga memiliki wewenang tersebut. Hal tersebut sejalan dengan apa dikemukakan oleh Philipus M. Hadjon yakni $^{5}$, bahwa minimal bagi penguasa jika ingin meletakan kewajiban-kewajiban pada warganya harus di dasarkan atas sebuah kewenangan yang diatur dengan tegas dalam ketentuan perundang-undangan yang berlkaku, yang dibentuk oleh lembaga pembentuk peraturan perundang-undangan (legislative).

Dalam hukum administrasi, sangat penting untuk mengetahui sumber dan cara memperoleh wewenang dari organ-organ pemerintahan. Karena akan berkenaan dengan pertanggungjawaban hukum (rechtelijke verantwording) dalam penggunaan wewenang tersebut, sesuai prinsip dalam negara hukum; "geen bevoegheid zonder verantwoordelijkheid atau there is no authority without

\footnotetext{
5 PhilipusM. Hadjon, 2002. Pengantar Hukum Administrasi Indonesia_Introduction to Indonesian Administrative Law, Gadja Mada University Press, Yogyakarta.hal 10
} 
responsibility" (tidak ada kewenangan tanpa pertanggungjawaban)" ${ }^{\prime 6}$.

Urain diatas menunjukan bahwa pemerintah dalam hal ini BPOM memerlukan dukungan hukum positif guna mengatur dan pengawasi peredaran minuman beralkohol. Hal ini sangat berkaitan dengan konsep Negara hukum dimana pokok pemikiran Negara hukum (rechstaatsdanken) di dasarkan atas asas “Wetmatigheids" ataupun "Legiliteit beginsel" sehingga hanya dengan kekuatan undang-undang maka kekuatan pemerintah dikatan sah dan mengikat. Lebih luas lagi bahwa negara Indonesia sebagai Negara hukum, maka tiada satupun perbuatan pemerintah yang berkaitan dengan kepentingan publik lepas dari hukum.

Sebagaimana diuraikan sebelumnya bahwa dalam melaksanakan tugas

\footnotetext{
6 , Ridwan,. 2008, Hukum Administrasi Negara, PT Grafindo Persada, Jakarta. Hal 108
}

pemerintah untuk melakukan pengawasan terhadap keamanan pangan tersebut maka dibentuklan lembaga pemerintah non departemen dalam sebuah keputusan presiden No 103 tahun 2001 tentang Kedudukan, Tugas, Fungsi, Kewenagan, Susunan Organisasi dan Tata Kerja Lembaga Negara Non Departemen atau yang disingkat dengan LPND yang mempunyai tugas melaksanakan tugas pemerintah tertentu dari presiden sebagaimana ketentuan peraturan perundang-undangan yang berlaku, salah satunya adalah Badan Pengawas Obat dan Makanan yang mempunyai Tugas melaksankan tugas pemerintah dibidang pengawasan obat dan makanan sesuai ketentuan peraturan perundang-undangan yang berlaku Sebagaimana tertuang dalam pasal 67 Keputusan Presiden tersebut.

Selanjutnya mengenai fungsi badan POM diatur dalam pasal 68 Keputusan 
Presiden tersebut yang terurai sevagai berikut:

a. Mengkaji dan menyusun kebijakan di bidang pengawasan obat dan makanan

b. Melaksanakan kebijakan tetentu di dalam pengawasan obat dan makanan

c. Melakukanj Kordinasi fungsional derngan instansi lain dalam melaksankan tugas BPOM

d. Melakukan pemantauan, memberikan bimbingan dan pembinaan terhadap kegiatan instansi pemerintah dan masyarakat dibidang pengawasan obat dan makanan

e. Menyelenggarakan pembinaan dan pelayanan administrasi umum dibidang perencanaan umum ketatausahaan, organisasi dan tatalaksana, kepegawaian, keuangan, kearsipan, hukum, persandian, perlengkapan dan rumah tangga

Dalam melaksanakan fungsi -fungsi

tersebut, maka dalam kepress diatur pula kewenangan badan BPOM sebagaimana pasal 69 sebagai berikut:

a. Penyusunan rencana nasional secara makro di bidangnya

b. Perumusan kebijakan di bidangnya untuk mendukung pembangunan secara makro

c. Penetapan sistem informasi di bidangnya

d. Penetapan persyaratan penggunaan bahan tambahan ( zat adiktif) tertentu untuk makanan dan menetapkan pedoman peredaran obat dan makan

e. Pemeberian izin dan pengawasan peredaran obat serta pengawasan industri farmasi

f. Penetapan pedoman penggunaan konservasi, pengembangan dan pengawasan tananama obat

Jika dikaitkan dengan pengawasan dan pengendalian minumana beralkohol oleh BPOM maka jelas dapat diketahui bahwa BPOM melaksanakan kewenagangannya dalam pasal 69 huruf d khusunya mengenai menetapkan pengawasan peredaran obat dan makanan, dimana selengkapnya berbunyi ; Penetapan persyaratan penggunaan bahan tambahan ( zat adiktif) tertentu untuk makanan dan menetapkan pedoman pengawasan peredaran obat dan makan

Dalam melaksanakan tugas pengawasan peredaran obat dan makanan maka selanjutnya BPOM mengacu pada Peraturan Menteri Kesehatan Republik Indonesia No 382/Menkes/Per/VI/ 1989 tentang Pendaftaran makanan . yang dalam ketentuan mewajibkan pendaftaran 
makanan baik makanan yang di import maupun yang di produksi langsung baik secara tradisional maupun modern, Dengan ketentuan ini maka setiap produsen maupun importir wajib mendaftarkan makananya di BPOM. Terhadap pangan olahan yang wajib di daftarkan baik yang di produksi sendiri maupun di masukan dari luar negeri ke dalam wilayah Indonesia wajib mencantumkan nomor pendaftaran pangan di label pangan olahan yang bersangkutan, hal ini sejalan dengan apa yang diuraikan dalam pasal 30 tentang pendaftaran makanan sebagaimana peraturan pemerintah No 69 Tahun 1999 tentang label dan iklan pangan Dengan demikian maka setiap makanan yang akan di edarkan di wilayah Republik Indonesia baik yang di produksi maupun di import dari luar negeri dalam label pangan olahannya harus mencantumkan Nomor pendaftaran pangan

Selain itu, mengenai Pendaftaran makanan telah diatur dalam Peraturan
Kepala badan Pengawas Obat dan makanan Republic Indonesia Nomor HK.03.1.5.12.11.09955 tahun 2011 tentang pendaftaran pangan olahan, dalam pasal 2 mewajibkan ; Setiap Pangan olahan baik yang di produksi di dalam negeri maupun yang di masukan kedalam wilayah Indonesia untuk diperdagangkan dalam kemasan eceran wajib memiliki surat persetujuan pendaftaran makanan dan minuman. Dengan demikian maka Pendaftaran pangan merupakan hal yang wajib dilakukan baik oleh produsen maupun importir, pendaftaran pangan olehan yang merupakan hasil produksi merupakan tanggungjwab perusahaan.

Selanjutnya sebagaimana ketentuan pasal 8 Peraturan kebala Badan Pengawas obat dan makanan yang intinya menyatakan bahwa pendaftaran pangan olahan yang di produksi sendiri dilakukan oleh Produsen, sedangkan pendaftaran pangan olahan yang dimasukan kedalam negeri di tanggung oleh 
importer atau distributor sesuai ketentuan

pasal 9 ayat (1) Peraturan Kepala badan

Pengawas Obat dan makanan

Selanjutnya bila dikaitakan dengan

kewenangan Badan POM dalam

pengendalian dan pengawasan minuman

beralkohol maka jelaslah minuman

beralkohol dikatagorikan kedalam pangan

yang merupakan hasil olahan, yaitu

makanan atau minuman hasil proses

dengan cara atau metode tertentu denagan

atau tampa bahan tambahan. Hal tersebut

sejalan pula dengan keputusan presiden no 3

tahun 1997 tentang pengawasan dan

pengendalian minuman beralkohol. Dalam

keputusan presiden tersebut di jelaskan pula

untuk melakukan pengawasan dan

pengendalian minuman beralkohol terdapat

beberapa kementrian yang terlibat yaitu :

Kementrian Perindutrian dan Perdagangan ,

menteri keuangan, menteri kesehatan

keterlibat kementerian tersebut sebagai

berikut Kementrian Perindutrian dan
Perdagangan dalam hal menetapkan ketentuan mengenai impor, pengedaran dan penjualan minuman beralkohol dan mengatur pula jenis atau produk minuman beralkohol yang bisa di perdagangakan di dalam negeri terlibat pula menteri keuangan dalam hal cukai, bea masuk dan pajak. Dan menteri kesehatan berkaitan dengan keamanan dan mutu makanan

Kewajiban untuk mendaftarkan semua produk makanan agar aman dikonsumsi termasuk minuman beralkohol, tidak terkecuali minuman beralkohol yang merupakan hasil industry rumah tangga baik yang di produksi secara tradisional maupun modern, terurai pula dalam peraturan kepala BPOM Nomor HK.03.1.5.12.11.09955 tahun 2011 tentang Pendaftaran Pangan Olahan. Berdasarkan ketentuan tersebut maka jelaslah BPOM memiliki kewenangan untuk melakukan pengawasan dan pengendalian minuman beralkohol, Pengawasan dilakukan melalui 
pendaftaran pangan diamana dalam

pendaftaran ini akan dilakukan pengujian laboratorium minuman beralkohol yang akan mengkaji apakah terhadap produkl makanan dan minuman tersebut telah memenuhi standar kesehatan dan syarat seauai dengan ketentuan yang berlaku atau tidak.

Bila di tinjau dari segi sumber kewenangan berkaitan dengan pengendalian dan pengawasan minuman beralkohol maka kewenangan Badan POM tersebut menurut H.D. van Wijk/Willem Konijnenbelt tergolong dalam; ${ }^{7}$ Delegatie : overdracht van een bevoegheid van het ene berstuitrsorgaan aan een ander, (delegasi adalah pelimpahan wewenang pemerintahan dan satu organ pemerintahan kepada organ pemerintahan lainnya). karena kewenangan tersebut berasal dari kewenagan pemerintah dalam hal ini presiden menerbitkan surat keputusan

\footnotetext{
${ }^{7}$ Ibid, hal.74
}

keputusan presiden No 103 tahun 2001 tentang Kedudukan, Tugas, Fungsi, Kewenagan, Susunan Organisasi dan Tata Kerja Lembaga Negara Non Departemen atau yang disingkat dengan LPND yang mempunyai tugas melaksanakan tugas pemerintah tertentu dari presiden sebagaimana ketentuan peraturan perundang-undangan yang berlaku, Badan yang dimaksud adalah Badan Pengawas Obat dan Makanan (Badan POM). Badan POM mempunyai Tugas melaksankan tugas pemerintah dibidang pengawasan obat dan makanan sesuai ketentuan hukum yang berlaku, hukum dalam hal ini adalah Undang-Undang pangan.

Selain itu apa bila tugas Badan POM di kaitkan dengan ketentuan Peraturan Menteri Kesehatan menurut PERMENKES No.382/MENKES/PER/VI/1989 tentang Pendaftaran Makanan, hal tersebut jelasjelas merupakan delegasi kewenangan yang diberikan oleh menteri kesehatan kepada 
Badan POM, dimana delegasi diartikan penyerahan wewenang oleh pejabat pemerintah atau pejabat tata usaha Negara kepada pihak lain, dalam hal ini menteri kesehatan memberikan kewenangan BPOM dalam melakukan pengawasan peredaran pangan khususnya bagi pangan olahan yang wajib di daftarkan. Hal ini terkait jelas dengan diterbitkannya Peraturan Kepala badan Pengawas Obat dan makanan Republic Indonesia Nomor HK.03.1.5.12.11.09955 tahun 2011 tentang pendaftaran pangan olahan.

Bila kewenagan badan POM dikaitkan dengan perda No 5 tahun 2012 tentang peredaran minumana alcohol di Bali maka jelas bahwa pemerintah daerah dalam hal ini gubernurlah yang memiliki kewenangan untuk itu mengatur dan melakukan pengendalian dan pengawasan peredaran minuman beralkohol. Walaupun Badan POM memiliki kewenagan yang sama dalam pengawasan dan pengendalian minuman beralkohol akan tetapi Perda No 5 tahun 2012 tentang peredaran minumana alcohol sama sekali tidak memberikan peluang bagi Badan POM untuk melakukan kewenagannya sebagaimana petunjuk teknis dalam hal pendaftaran makanan yang di dasarkan pada Peraturan Menteri Kesehatan Republik No 382/Menkes/Per/VI/ 1989 tentang Pendaftaran makanan. Yang mewajibkan semua makanan haruslah di daftarkan melalui BPOM .

Dengan demikian dapat dikatakan bahwa Perda No 5 Tahun 2015 mengandung kekosongan norma (vacum of norm atau leemten) mengenai kewenagan Badan POM dalam pengawasan dan pengendalian minuman beralkohol di Bali . ini berarti bahwa Peraturan perundangundangan yang dibuat tidak mengatur seluruh permasalahan yang timbul dalam kehidupan bermasyarakat sehingga menyulitkan bagi aparat penegak hukum untuk menyelesaikan permasalahan tersebut. 
terhadap hal tersebut maka penyelesaiannya berpegang pada asas ius curia novit atau pemerintah segera membuataperda yang baru mensinkronisasikan kewenagan BPOM dengan Kewenangan Pemda dalam melakukan pengawasan dan penertiban peradaran minuman beralkohol di Bali

\section{SIMPULAN DAN SARAN}

\section{Simpulan}

Secara Normatif dalam perda Bali No 5 Tahun 2012 tentang Pengawasan dan Pengendalian Minuman beralkohol di Bali jelas-jelas tidak mengatur tentang kewenangan Badan POM untuk melakukan penegawasan dan pengendalian minuman beralkohol di Bali (norma kosong). Padahal jelas Badan POM memiliki kewenangan di seluruh Indonesia melalui peraturan menteri kesehatan. Kewenangan Badan Pengasan Obat dan Makanan dalam melakukan pengawasan dan pengendalian minuman beralkohol menurut permenkse
No.382/MENKES/PER/VI/1989 tentang Pendaftaran Makanan mewajibkan semua makanan yang akan di edarkan di masyarakat harus di daftarkan terlebih dahulu ke Badan POM untuk memperoleh no mor pendaftaran makanan dan minuman.

\section{Saran}

Harus dilakukan perubahan terhadap perda Bali No 5 Tahun 2012 tentang Pengawasan dan Pengendalian Minuman beralkohol di Bali yang selama ini jelasjelas tidak mengatur tentang kewenangan BPOM untuk melakukan penegawasan dan pengendalian minuman beralkohol di Bali (norma kosong) . Sehingga terjadi sinkronisasi kerja kedua lembaga ini dalam melakukan pengawsan dan pengendalian minuman beralkohol di Bali 
DAFTAR PUSTAKA

\section{Buku.}

Hadjon, PhilipusM 2002. Pengantar Hukum Administrasi Indonesia_Introduction to Indonesian Administrative Law, Gadja Mada University Press, Yogyakarta.

HR. Ridwan,. 2008, Hukum Administrasi Negara, PT Grafindo Persada, Jakarta.

Suryana, Achmad., 2003, Kapita Selekta Pemikiran Kebijakan Ketahanan Pangan, Cet Pertama, BPFE-yogyakarta, Yogyakarta.

\section{Internet.}

Ithalabo, blog,DampakMminuman Keras, senin 8 juni 2012

Miras Bukan Lagi Barang Mewah: Harus Dikendalikan dengan UU, by Neo KPPP ASI (Komunitas Pengamat Pengkaji Pengamal Aqidah Syariat Islam) on Sunday, January 15, 2012 at 6:21pm

http:// balinews.blog.com PAD+Minuman+beralkohol+di+bali+tahun $+2010$

\section{Peraturan}

- Undang-Undang Nomor 7 tahun 1986 tentang Pangan

- Peraturan pemerintah Republik Indonesia Nomor 69 tahun 1999 tentang Label dan Iklan Pangan

- Peraturan pemerintah Republik Indonesia Nomor 28 tahun 2004 tentang Keamanan, Mutu dan Gizi Pangan

- Keputusan Presiden No 166 tahun 2000, tentang Kedudukan Tugas, Fungsi, Kewenangan,
Susunan Organisasi dan Tata Kerja Lembaga Pemerintah Non Departemen

- Keputusan Presiden Nomor 3 tahun 1997 tentang Pengawasan dan Pengendalian minuman beralkohol

- Keputusan Menteri Kesehatan Republik Indonesia NO. 1700/B/SK/VII/82 tentang Penolakan Pendaftaran Jenis Tertentu Minuman Keras dan Makanan/Minuman yang Mengandung Alkohol

- Keputusan Menteri Kesehatan Republik Indonesia NO.282/ MENKES/SK/1998 tentang Standar Mutu Produksi Minuman Beralkohol

- Peraturan Menteri Kesehatan NO.

382/MENKES/PER/VI/1989 tentang Pendaftaran Makanan 